\title{
Stakeholder Involvement and Policy Changes of Healthy City Implementation in Makassar City
}

\author{
Inayyah Nur Fitry S*, Sukri Palutturi, Ridwan M. Thaha, Siradjuddin \\ Department of Health Administration and Policy, Faculty of Public Health, Hasanuddin University, Makassar, Indonesia
}

\section{*Corresponding Author}

Inayyah Nur Fitry S

\section{Article History}

Received: 15.10 .2019

Accepted: 22.10 .2019

Published: 02.11.2019

\begin{abstract}
The healthy city program in Makassar City has been implemented since 2007. The implementation of the program has had various impacts on the progress of the Makassar city. This research was conducted to evaluate the impact of stakeholder involvement and the impact of city policy changes as a result of implementing a healthy city program in Makassar. The research method used was a qualitative research design with a phenomenological approach. The study was conducted in the city of Makassar, with 13 informants. Data collection techniques used was in-depth interviews and document review. Data analysis was performed using data presentation techniques. Based on the results of the study note the impact on stakeholder involvement in the implementation of healthy cities in Makassar city is not only the government, but also includes the community and the Makassar healthy city forum, each of which has a role that can help the progress of the city of Makassar. In addition, the implementation of healthy cities directly affects various policies that already exist in Makassar, and even the implementation of healthy cities can produce a variety of new regulations that are also able to support the progress of the city of Makassar. The implementation of a healthy city in Makassar has two major impacts, namely stakeholder involvement and influence in policy, both of which have shown quite good results
\end{abstract}

Keywords: Healthy city, stakeholders, policy, evaluation, implementation.

\section{INTRODUCTION}

Urbanization has become a phenomenon that seems difficult to stem. The attraction of the city with all its facilities has attracted thousands and even millions of people to move [1]. WHO [2] states that the proportion of the population living in cities increased from $5 \%$ to $50 \%$ over the past two centuries.

Increased urbanization has social, economic and environmental impacts. Health impacts are related to various aspects such as the environment (sanitation), transportation and mobility issues (pollution, stress), increasing crime and violence, the spread of HIV I AIDS cases, and increasing vulnerability of other urban populations [3].

Various problems then arise due to the accelerated growth of urbanization such as increasing demand for food and the availability of clean water, healthy housing, good waste disposal, and adequate health services [4]. In an effort to overcome these urban problems, the World Health Organization (WHO) in the 1980s introduced a concept that was considered a comprehensive approach aimed at facilitating and creating a healthier urban environment. The concept is Healthy City or Healthy City [5].

Cities play an important role in the social fabric of the country and national and regional economies throughout the world. In theory and public opinion, the city offers opportunities for education, employment, services, and cultural enrichment, and hopes for better health. In fact, these opportunities may not be as busy as expected [6].

Healthy City has been running for more than 1 (one) decade in Indonesia. However, it is still felt and even academic debate is still happening about the facts of the field which shows that environmental and social health problems are still a major problem in urban areas, but the district / city gets healthy city awards from the central government at the highest level [5].

Copyright @ 2019: This is an open-access article distributed under the terms of the Creative Commons Attribution license which permits unrestricted use, distribution, and reproduction in any medium for non commercial use (NonCommercial, or CC-BY-NC) provided the original author and source are credited. 
The program for the realization of a healthy city in Makassar has been started since 2007. In Makassar a Healthy Cities Forum has been formed which functions as an institution that facilitates the realization of the Healthy Cities program [7]. However, in its implementation, the Healthy Cities program in Makassar City did not run as smoothly as imagined. Behind these achievements, the concept of Healthy Cities in Makassar still needs to be evaluated more deeply. The lack of community and stakeholder participation is one of the main causes of the still many urban problems that occur in Makassar City, especially regarding the health sector. In addition, the implementation of a healthy city in Makassar also has an impact on changes in city policies related to the healthy city program. Changes in policy as well as the participation of various parties that can enable the sustainability of the healthy city program in the future.

Evaluation of a program or policy needs to be done to answer whether differences have been made from the implementation of a program [8]. Evaluation is also intended as an illustration in seeing some of the failure of a program or policy and to find out whether policies that have been formulated and implemented can produce the desired impact [9]. The importance of identifying evaluations of the impact of interventions has been emphasized by Rossi et al. [10]. Therefore, this study was conducted to evaluate the impact of the implementation of healthy cities in Makassar, namely the impact of stakeholder involvement and the impact of policy changes.

\section{MethOdS}

This research is a qualitative research with a phenomenological approach. The study was conducted in Makassar City on March 21 - May 3, 2019, with 19 informants. The informants consisted of 10 informants who were the heads of the healthy subdistrict forums in 10 subdistricts from 15 subdistricts in Makassar City, 1 informant from the responsible person of the healthy city namely Makassar Deputy Mayor, 1 informant from the Makassar City Regional Planning and Development Board, 1 informant from the City Health Office Makassar, 1 informant from the Makassar City Transportation Office, 1 informant from the Makassar City Culture and Tourism Service, 1 informant from the Makassar City Public Works Service, 1 informant from the Makassar City Industry Service, 1 informant from the Makassar City Social Service, and 1 informant from the Makassar City Service Makassar City Food Security.

Data sources from this research are primary data and secondary data. Data will be collected through direct interviews, observations, and document review. After the data is collected, it is then reduced and processed into abstractions, then made in the form of a matrix, and presented in narrative form.

\section{RESULTS \\ Stakeholder Involvement}

Based on the results of in-depth interviews related to stakeholder involvement in the implementation of a healthy city in Makassar, it was found that there had been a significant change since the existence of the healthy city program in Makassar City. Stakeholders in implementing healthy cities are not only the government, but also involve the community, which is the main target in implementing healthy cities. The community actively plays a role in various programs implemented related to the healthy city program. In addition there was an increase in mindset about clean and healthy lifestyles as well as environmental conditions and a better quality of life.

Government involvement in this matter is the mayor, deputy mayor and all related SKPDs are key stakeholders in the implementation of the healthy city program in Makassar. In addition to the government and the community, the healthy city forum is also considered as one of the important elements in implementing a healthy city program. Healthy city forums are considered as a driving force and a liaison between the government and the community in carrying out various activities related to healthy cities.

\section{Policy Changes}

Based on the results of in-depth interviews with all informants regarding the policy of healthy cities in Makassar, it is known that there are no regional regulations or specific policies that contain the implementation of healthy city programs in Makassar. The regulations or policies relating to healthy cities in the city of Makassar are the Decree or Decree of the Mayor of Makassar No. 440.05 / 217 / Kep / / 2014 concerning the Establishment of the Makassar Healthy City Forum.

In addition, based on the results of in-depth interviews with policy changes it is known that the majority of informants are of the opinion that since the healthy city program in Makassar was implemented there were a variety of policy changes both at the city government level and in each related SKPD responsible for the healthy city program. The following is a table related to policies or regulations that were born and changed since the implementation of a healthy city in Makassar based on each order. 
Table-1: Regulations related to Healthy City Program in Makassar City

\begin{tabular}{|c|c|c|}
\hline $\begin{array}{l}\text { HC Setting in } \\
\text { Makassar }\end{array}$ & Indicators & Regulations related \\
\hline \multirow{11}{*}{$\begin{array}{l}\text { Residential Areas, } \\
\text { Healthy Facilities } \\
\text { and Infrastructure }\end{array}$} & - Clean air & $\begin{array}{l}\text { - Local regulation No. } 9 \text { of } 2016 \text { concerning Environmental Protection and } \\
\text { Management }\end{array}$ \\
\hline & - $\quad$ Clean river water & $\begin{array}{l}\text { - Local regulation No. } 9 \text { of } 2016 \text { concerning Environmental Protection and } \\
\text { Management }\end{array}$ \\
\hline & $\begin{array}{l}\text { - Provision of individual \& public } \\
\text { clean water }\end{array}$ & $\begin{array}{l}\text { - Local regulation No. } 11 \text { of } 2006 \text { concerning the Second Amendment to } \\
\text { Regional Regulations } \\
\text { - Ujung Pandang District Level II Municipality No. } 6 \text { of } 1974 \text { concerning the } \\
\text { Establishment of Ujung Pandang Level II Regional Water Supply Company }\end{array}$ \\
\hline & $\begin{array}{l}\text { - Disposal of water waste domestic } \\
\text { (household) }\end{array}$ & $\begin{array}{l}\text { - Local regulation No. } 1 \text { of } 2016 \text { concerning Domestic Waste Water } \\
\text { Management }\end{array}$ \\
\hline & - Waste Management & $\begin{array}{l}\text { - Local regulation No. } 11 \text { of } 2011 \text { concerning Solid Waste Service Levies } \\
\text { - Local regulation No. } 4 \text { of } 2011 \text { concerning Waste Management }\end{array}$ \\
\hline & - Healthy housing \& Settlement & $\begin{array}{l}\text { - Local regulation No. } 9 \text { of } 2011 \text { concerning Provision \& Delivery of } \\
\text { Infrastructure, Facilities, Utilities in Industrial, Trade, Housing and Settlement } \\
\text { Zones } \\
\text { - Local regulation No. } 10 \text { of } 2011 \text { concerning Management of Boarding Houses }\end{array}$ \\
\hline & - Landscape and forest town & $\begin{array}{l}\text { - Local regulation No. } 3 \text { of } 2014 \text { concerning the Arrangement and } \\
\text { Management of Green Open Spaces }\end{array}$ \\
\hline & - School & $\begin{array}{l}\text { - Local regulation No. } 3 \text { of } 2006 \text { concerning Implementation of Education } \\
\text { - Mayor's Regulation No. } 31 \text { of } 2017 \text { concerning Guidelines for Quality } \\
\text { Voluntary Education Donations }\end{array}$ \\
\hline & - $\quad$ Market management & $\begin{array}{l}\text { - Local regulation No. } 15 \text { of } 2009 \text { concerning Protection, Empowerment of } \\
\text { Traditional Markets \& Structuring of Modern Markets in Makassar City }\end{array}$ \\
\hline & $\begin{array}{l}\text { - Sports, recreation, and } \\
\text { playground facilities }\end{array}$ & $\begin{array}{l}\text { - Local regulation No. } 9 \text { of } 2011 \text { concerning Provision \& Delivery of } \\
\text { Infrastructure, Facilities, Utilities in Industrial, Trade, Housing and Settlement } \\
\text { Zones } \\
\text { - Mayor's Regulation No. } 100 \text { of } 2016 \text { concerning Position, Organizational } \\
\text { Structure, Duties \& Functions and Work Procedures of the Youth \& Sports } \\
\text { Agency } \\
\text { - Regional Regulation No. } 2 \text { of } 2009 \text { concerning Government Affairs which } \\
\text { become the Authority of Makassar City Government }\end{array}$ \\
\hline & - Informal sector structuring & $\begin{array}{l}\text { - Mayor's Decree No. } 651 \text { of } 2007 \text { concerning the Road Quadrangle Region as } \\
\text { a Pilot Model for Sanitation \& Enforcement of the City of Makassar }\end{array}$ \\
\hline \multirow{6}{*}{$\begin{array}{l}\text { An Orderly Area of } \\
\text { Traffic \& } \\
\text { Tranportation } \\
\text { Services }\end{array}$} & - $\quad$ Public transports facilities & $\begin{array}{l}\text { - Mayor's Regulation No. } 49 \text { of } 2014 \text { concerning Adjustment of Microbuses } \\
\text { Type Public Transportation Rates in the Makassar City Region }\end{array}$ \\
\hline & - Terminal and bus stop facilities & $\begin{array}{l}\text { - Local regulation No. } 15 \text { of } 2006 \text { concerning Management of the Passenger } \\
\text { Terminal } \\
\text { - Mayor's Regulation No. } 4 \text { of } 2016 \text { concerning the Organizational Structure } \\
\text { and Working Arrangement of Makassar Metro Makassar City Region }\end{array}$ \\
\hline & - $\quad$ Accident prone & $\begin{array}{l}\text { - Mayor's Regulation No. } 2 \text { of } 2018 \text { Guidelines for the Implementation of } \\
\text { Pasikola Shuttle } \\
\text { - Mayor's Regulation No. } 96 \text { of } 2016 \text { concerning the Position, Organizational } \\
\text { Structure, Duties and Functions and Work Procedures of the Transportation } \\
\text { Agency }\end{array}$ \\
\hline & - $\quad$ Traffic management & \multirow{3}{*}{$\begin{array}{l}\text { - Mayor's Regulation No. } 145 \text { of } 2009 \text { concerning the Establishment of Pilot } \\
\text { Areas for Security, Safety, Order and Smooth Traffic }\end{array}$} \\
\hline & - $\quad$ Orderly traffic \& safety & \\
\hline & - $\quad$ Social & \\
\hline \multirow{5}{*}{$\begin{array}{l}\text { Healthy Industrial \& } \\
\text { Office Area }\end{array}$} & $\begin{array}{l}\text { - Testing of solid waste \& liquid } \\
\text { waste pollution }\end{array}$ & $\begin{array}{l}\text { - Mayor's Regulation No. } 32 \text { of } 2018 \text { concerning the Master Plan for Domestic } \\
\text { Wastewater Management }\end{array}$ \\
\hline & $\begin{array}{l}\text { - Restricting community-based } \\
\text { industrial estate }\end{array}$ & \multirow{2}{*}{$\begin{array}{l}\text { - Local regulation No. } 9 \text { of } 2011 \text { concerning Provision \& Delivery of } \\
\text { Infrastructure, Facilities, Utilities in Industrial, Trade, Housing and Settlement } \\
\text { Zones }\end{array}$} \\
\hline & $\begin{array}{l}\text { Business group/work information } \\
\text { sector In the industrial } \\
\text { environment }\end{array}$ & \\
\hline & $\begin{array}{l}\text { Occupational safety \& health and } \\
\text { prevention of accidents and } \\
\text { forced labor }\end{array}$ & $\begin{array}{l}\text { - Mayor's Regulation No. } 99 \text { of } 2015 \text { concerning Procedures for Provision, } \\
\text { Disbursement and Accountability of Work Accident Guarantee Funds \& } \\
\text { Mortality Insurance for Employees Working in Makassar City Government }\end{array}$ \\
\hline & $\begin{array}{l}\text { - Socio-economic and cultural and } \\
\text { public health }\end{array}$ & $\begin{array}{l}\text { - Mayor's Regulation No. } 6 \text { of } 2016 \text { concerning 24-Hour Home Visit Services in } \\
\text { Makassar City } \\
\text { - Mayor's Regulation No. } 131 \text { of } 2016 \text { concerning the Determination of the } \\
\text { Status and Working Network of the Technical Implementation Unit of the }\end{array}$ \\
\hline
\end{tabular}




\begin{tabular}{|c|c|c|}
\hline & & Hospital and Community Health Centers at the Makassar City Health Office \\
\hline \multirow{5}{*}{$\begin{array}{l}\text { Healthy Tourism } \\
\text { Area }\end{array}$} & - Travel and health information & - Local regulation No. 5 of 2011 concerning Tourism Business Registry \\
\hline & - Tourism facilities & - Local regulation No. 5 of 2011 concerning Tourism Business Registry \\
\hline & - Tourist objects and attractions & - Local regulation No. 5 of 2011 concerning Tourism Business Registry \\
\hline & - Health services & - Local regulation No. 2 of 2013 concerning Preservation of Cultural Heritage \\
\hline & - Supporting facilities & $\begin{array}{l}\text { - Local regulation No. } 12 \text { of } 2011 \text { concerning General Service Levies } \\
\text { - Local regulation No. } 5 \text { of } 2012 \text { concerning Certain Licensing Levies }\end{array}$ \\
\hline \multirow{5}{*}{$\begin{array}{l}\text { Food Security \& } \\
\quad \text { Nutrition }\end{array}$} & - Availability & \multirow{5}{*}{$\begin{array}{l}\text { - Mayor's Regulation No. } 92 \text { of } 2016 \text { concerning Position, Organizational } \\
\text { Structure, Duties and Functions and Work Procedures of the Office of Food } \\
\text { Security. } \\
\text { - Regional Regulation No. } 4 \text { of } 2015 \text { concerning Makassar City Spatial } \\
\text { Planning for 2015-2034 }\end{array}$} \\
\hline & - Distribution & \\
\hline & - Consumption & \\
\hline & - Vigilance & \\
\hline & - $\quad$ Social & \\
\hline \multirow{16}{*}{$\begin{array}{l}\text { Independent Healthy } \\
\text { Community Life }\end{array}$} & $\begin{array}{l}\text { - Clean \& healthy life behavior in } \\
\text { the household setting }\end{array}$ & - Local regulation No. 7 of 2009 concerning Health Services in Makassar City \\
\hline & - $\quad$ Public places & $\begin{array}{l}\text { - Healthy Hallway program policies, No-Smoking Areas, etc. } \\
\text { - Local regulation No. } 64 \text { of } 2011 \text { concerning Management of Roadside } \\
\text { Parking }\end{array}$ \\
\hline & - Housing, and healthy buildings & $\begin{array}{l}\text { - Local regulation No. } 9 \text { of } 2011 \text { concerning Provision \& Delivery of } \\
\text { Infrastructure, Facilities, Utilities in Industrial, Trade, Housing and Settlement } \\
\text { Zones }\end{array}$ \\
\hline & $\begin{array}{l}\text { - Family health, family planning } \\
\text { reproduction }\end{array}$ & $\begin{array}{l}\text { - Local regulation No. } 7 \text { of } 2009 \text { concerning Health Services in Makassar City } \\
\text { - Mayor's Regulation No. } 95 \text { of } 2016 \text { concerning the Position, Organizational } \\
\text { Structure, Duties \& Functions and Work Procedures of the Population and } \\
\text { Family Planning Control Office }\end{array}$ \\
\hline & $\begin{array}{ll} & \text { Fostering community mental } \\
& \text { health \& parenting }\end{array}$ & - Regulation No. 5 of 2018 on Child Protection \\
\hline & - Sports health and physical fitness & - Local regulation No. 7 of 2009 concerning Health Services in Makassar City \\
\hline & - Anti-tobacco program & - Regulation No. 4th of 2013 on Non-Smoking Area (KTR) \\
\hline & - immunization & $\begin{array}{l}\text { - Local regulation No. } 3 \text { of } 2016 \text { concerning Exclusive Breastfeeding } \\
\text { - Local regulation No. } 12 \text { of } 2011 \text { concerning General Service Levies }\end{array}$ \\
\hline & - $\quad$ Treatment \& care services & - Local regulation No. 7 of 2009 concerning Health Services in Makassar City \\
\hline & - Malaria eradiction & \multirow{7}{*}{$\begin{array}{l}\text { - Local regulation No. } 7 \text { of } 2009 \text { concerning Health Services in Makassar City } \\
\text { - Local regulations No. } 83 \text { of } 2016 \text { concerning the Position, Organizational } \\
\text { Structure, Duties and Functions and Work Procedures of the Health Service }\end{array}$} \\
\hline & - $\quad$ DHF eradiction & \\
\hline & - $\quad$ Pulmonary TB eradiction & \\
\hline & - $\quad$ Diarrhea eradiction & \\
\hline & $\begin{array}{l}\text { - Prevention of degenerative } \\
\text { diseases }\end{array}$ & \\
\hline & - $\quad$ nutrition & \\
\hline & - JPKM & \\
\hline \multirow{4}{*}{ Healthy Social Life } & $\begin{array}{l}\text { - Handling poverty and social } \\
\text { descent }\end{array}$ & $\begin{array}{l}\text { - Mayor's Regulation No. } 89 \text { of } 2016 \text { concerning the Position, Organizational } \\
\text { Structure, Duties and Functions and Work Procedures of the Social Service } \\
\text { - Mayor's Regulation No. } 70 \text { of } 2015 \text { concerning the Strategy to Accelerate } \\
\text { Regional Poverty Reduction }\end{array}$ \\
\hline & - $\quad$ Handling disability & $\begin{array}{l}\text { - Local regulation No. } 6 \text { of } 2013 \text { concerning Fulfillment of the Rights of } \\
\text { Persons with Disabilities }\end{array}$ \\
\hline & $\begin{array}{l}\text { - Handling neglected children and } \\
\text { elderly }\end{array}$ & $\begin{array}{l}\text { - Local regulation No. } 2 \text { of } 2008 \text { concerning the Coaching of Street Children, } \\
\text { Bums, Beggars and Buskers in Makassar City }\end{array}$ \\
\hline & $\begin{array}{l}\text { - Prevention of victims of natural } \\
\text { disasters, violence and riots. }\end{array}$ & $\begin{array}{l}\text { - Mayor's Regulation No. } 89 \text { of } 2016 \text { concerning the Position, Organizational } \\
\text { Structure, Duties and Functions and Work Procedures of the Social Service }\end{array}$ \\
\hline
\end{tabular}
Sources: Primary Data, 2019

\section{Discussion}

Policy evaluation is related to the impact of policies on the problems that are targeted by the policy [11]. Evaluation refers to the extent to which the results are observed. Based on the results of the study, the healthy city program in Makassar City has been running as it should and has had a significant impact, which is related to stakeholder involvement and policy changes within the scope of the city of Makassar.

Involvement is an interest or motivational part that is generated by a particular stimulus or situation, and is addressed through the appearance characteristics [12]. Meanwhile, according to WHO [13] the level of involvement is how much participation from the community in the implementation of a program or activity. 
Based on stakeholder involvement, it is known that not only the government is involved, but also the community which is considered as one of the key stakeholders in implementing a healthy city program in Makassar City. In this case the community is the primary stakeholder, while the government is a secondary stakeholder. Stakeholder involvement is related to two factors, namely the level of knowledge about the program and the healthy city program management structure. In Makassar City, understanding of healthy cities is good enough. All informants interviewed were aware of the healthy city program and were often involved in carrying out activities related to the healthy city, but their understanding of the program was still lacking.

However, the management structure of the implementation of the healthy city program in Makassar City is still considered quite well. The management structure in implementing a healthy city in Makassar is run by a healthy city forum formed by the government involving various sectors. The forum is a forum for the community to channel their aspirations and participate. In the Regency / City it is called the District/City healthy forum or other name agreed by the community. The forum should involve all agencies, including the private sector and existing NGOs and the community. To involve the community, it is hoped that the forum will be formed starting from the top level (city) to the bottom level in the form of Work (Pokja). Thus the effort to improve health is the responsibility of all sectors, society and the private sector [14].

The results of this study are in line with research conducted by WHO [13] in the City of Fayoum, Egypt. The results of the study stated that public knowledge about the Healthy City is only limited to one specific activity that only involves certain stakeholders. The results of this study are also in line with research conducted by Hapsari et al. [15], which states that a common problem related to healthy cities is due to lack of socialization from the government, so people are not aware of the healthy city program.

Stakeholder involvement, one of which is the government, does not only cover one SKPD but also almost all SKPDs related to the healthy city order in the city of Makassar. Based on the results of the study, it is known that the Makassar city government does not issue special regional regulations related to the implementation of healthy cities in the city of Makassar. However, it is known that there are various regulations or policies that were born since the implementation of healthy cities in Makassar city in 2007. Regulations that were born and changed since the implementation of healthy cities in Makassar City have a very significant impact on the progress of Makassar. Various city government programs were born and helped to advance the city of Makassar and make the city of Makassar as one of the pilot cities in Indonesia. These programs include the hallway garden program, healthy hallway, garbage bank, and so on. In addition, media coverage, both print and electronic, also influences the development of policies and community participation related to healthy cities. In this healthy city program, it is usually covered by local newspapers, even in national newspapers and television.

Based on the results of the study, researchers saw that there were several factors that affected the ability of the healthy city program to influence policy, including: the distribution of responsibilities and cooperation between the central, provincial, and district / city governments; the ability of the healthy city program coordinator in this case is a healthy city forum to influence politicians, as well as existing policies. Achieving changes in city policy may take more than three to four years to achieve, especially in places where there is no political stability.

The results of this study are in line with research conducted in the city of Quetta, Pakistan [16]. A representative from the Quetta Development Authority reported that their next policy document (to be released in 1999/2000) would reflect many of the problems that had been learned through membership in the healthy city forum/healthy city technical committee, for example understanding of the need for community involvement in planning and implementation is something that he has obtained from his participation in the healthy city program.

\section{CONCLUSION}

Based on the research that has been done, it can be concluded that the involvement of stakeholders in the implementation of healthy cities in Makassar city not only involves the government, but also the role of the community and healthy city forums is also very important. In addition, the implementation of healthy cities in Makassar also greatly influenced the birth of new regulations and changes in regulations that were considered capable of supporting the implementation of healthy cities themselves.

\section{REFERENCES}

1. Harahap, F.R. (2013). Dampak Urbanisasi Bagi Perkembangan Kota di Indonesia. Jurnal Society UBB 1(1).

2. World Health Organization (WHO). (2010). Why urban health matters (No. WHO/WKC/WHD/2010.1). Geneva: World Health Organization.

3. Paluttur, S. (2017). Healthy Cities: Konsep Global, Implementasi Lokal untuk Indonesia. Pustaka Pelajar, Yogyakarta.

4. Hidayat, A., Abikusno, N., Kusumaratna, K.R., \& Surjawidjaja E.J. (2003). Membangun Kota Sehat Melalui Perilaku Sehat dan Beradab Menyongsong Indonesia Sehat 2010. Jurnal Kedokteran Trisakti.

5. Palutturi, S., Rutherford, S., Davey, P., \& Chu C. (2013). Comparison Between Healthy Cities and Adipura in Indonesia. Malaysian Journal of Medicine and Health Sciences, 9(1), 35-43. 
6. Moore, M., Gould, P., \& Keary, B. S. (2003). Global urbanization and impact on health. International journal of hygiene and environmental health, 206(4-5), 269-278.

7. Makassar City Health Office. (2018). Penyelenggaraan Kota Sehat di Makassar. Makassar, Indonesia.

8. Wahyudi A. (2010). Evaluasi Dampak Program Rumah Susun di Kota Surakarta. Doctoral dissertation, Universitas Sebelas Maret.

9. Agustino, L. (2008). Dasar-dasar Kebijakan Publik. Penerbit Alfabeta, Bandung.

10. Rossi, P.H., Lipsey M.W., \& Henry G.T. (1999). Evaluation: A systematic approach. Sage Publications.

11. Hartanto, R. V. P., \& Firdausy, A. G. (2010). Evaluasi terhadap Pelaksanaan Instruksi Presiden Nomor 9 Tahun 2000 tentang Kebijakan Pengarusutamaan Gender Oleh Pemerintah Kota Surakarta. Yustisia, 45-54.

12. Japarianto, E., \& Sugiharto S. (2012). Pengaruh shopping life style dan fashion involvement terhadap impulse buying behavior masyarakat high income surabaya. Jurnal Manajemen Pemasaran, 6(1), 32-41.

13. World Health Organization, (WHO). (2000). Healthy cities in action: WHO/UNDP-LIFE Healthy City Projects in five countries: an evaluation (No. WHO/SDE/PHE/00.02). Geneva: World Health Organization.

14. Mulasari, S.A. (2019). Membangun Kota Sehat (Healthy City) Menuju Indonesia Sehat Berkemajuan. Jurnal Pemberdayaan: Publikasi Hasil Pengabdian Kepada Masyarakat, 2(2), 187-194.

15. Hapsari, D., Sari P., Afifah T., \& Suriani, O. (2007). Gambaran Kebijakan Penyelenggaraan Kota Sehat pada Lima Kota di Indonesia. Media Litbang Kesehatan, Volume XVII Nomor 3. Halaman, 19-28.

16. Werna, E. (1995). Quetta Healthy City Programme, Pakistan - start-up phase. Consultancy Report for WHO. Geneva: World Health Organization. 